\title{
Effect of fungicide application to control Fusarium head blight and 20 Fusarium and Alternaria mycotoxins in winter wheat (Triticum aestivum L.)
}

\author{
V. Scarpino ${ }^{1}$, A. Reyneri ${ }^{1}$, M. Sulyok ${ }^{2}$, R. Krska ${ }^{2}$ and M. Blandino ${ }^{1^{*}}$ \\ ${ }^{1}$ University of Turin, Department of Agricultural, Forest and Food Sciences, Largo Paolo Braccini 2, 10095 Grugliasco (TO), \\ Italy; ${ }^{2}$ Center for Analytical Chemistry, Department for Agrobiotechnology (IFA-Tulln), University of Natural Resources \\ and Life Sciences, Vienna (BOKU), Konrad-Lorenz-Str. 20, Tulln 3430, Austria; massimo.blandino@unito.it
}

Received: 5 August 2014 / Accepted: 11 October 2014

(c) 2014 Wageningen Academic Publishers

RESEARCH ARTICLE

\begin{abstract}
Azole fungicides have been reported to be the most effective active substances in the control of Fusarium Head Blight (FHB) and in the reduction of the main mycotoxins that occur in cereal grain, such as deoxynivalenol (DON). Four field experiments have been conducted in North West Italy, over a period of 2 growing seasons, in order to evaluate the effect of azole fungicide (prothioconazole) applications on the prevalence of emerging mycotoxins in common winter wheat under naturally-infected field conditions. Wheat samples have been analysed by means of a diluteand-shoot multi-mycotoxin LC-MS/MS method. Twenty fungal metabolites were detected: enniatins, aurofusarin, moniliformin, equisetin, DON, deoxynivalenol-3-glucoside, culmorin, bikaverin, beauvericin, fumonisins, fusaric acid, 3-acetyldeoxynivalenol, 15-acetyldeoxynivalenol, nivalenol, zearalenone, decalonectrin, butenolide, tentoxin, alternariol and alternariol methyl ether. The most abundant fungal metabolites were DON and culmorin, with an average contamination in the untreated control of 1,360 $\mu \mathrm{g} / \mathrm{kg}$ and $875 \mu \mathrm{g} / \mathrm{kg}$, respectively, in the growing season with the highest disease pressure (2011-2012). On average, the results have shown that the fungicide application significantly reduced the enniatins (from $127 \mu \mathrm{g} / \mathrm{kg}$ to $46 \mu \mathrm{g} / \mathrm{kg}$ ), aurofusarin (from $62 \mu \mathrm{g} / \mathrm{kg}$ to $21 \mu \mathrm{g} / \mathrm{kg}$ ), moniliformin (from $32 \mu \mathrm{g} / \mathrm{kg}$ to $16 \mu \mathrm{g} / \mathrm{kg}$ ), tentoxin (from $5.2 \mu \mathrm{g} / \mathrm{kg}$ to $2.5 \mu \mathrm{g} / \mathrm{kg}$ ) and equisetin (from $0.72 \mu \mathrm{g} / \mathrm{kg}$ to $0.06 \mu \mathrm{g} / \mathrm{kg}$ ) contents in all the experiments. However, DON, deoxynivalenol-3-glucoside and culmorin were only significantly reduced in the growing season with the highest disease pressure. The other fungal metabolites were mainly found in traces in the untreated plots. These results, which have been obtained in different environmental and agronomic conditions, have underlined for the first time that the fungicide usually applied to control the FHB and DON content, also consistently reduces the main emerging mycotoxins of winter wheat in temperate areas.
\end{abstract}

Keywords: prothioconazole, deoxynivalenol, enniatins, moniliformin, aurofusarin

\section{Introduction}

The fungal diseases that affect wheat ears (Triticum aestivum L.) cause worldwide yield losses and promote the production of mycotoxins in cereal grains, as well as the contamination of wheat-derived feed and food products, with a negative impact on their safety and quality. Fusarium Head Blight (FHB) is the most widespread wheat ear disease, it causes total or partial premature ear senescence and consequently reduces both crop yields and grain quality. Several varieties of fungi, including Microdochium nivale, and different Fusarium species could most probably be involved in promoting this disease (Champeil et al., 2004). Among the Fusarium species, Fusarium graminearum and Fusarium culmorum are the most important FHB agents, and are the main causes of the production and the accumulation of type- $\mathrm{B}$ trichothecene deoxynivalenol (DON).

DON is responsible for serious mycotoxicosis in humans and animals. Several reports have suggested that the presence of DON in human food raises potential serious safety issues, particularly anorexia and vomiting (Pestka and Smolinski, 2005). Since DON is the most prevalent 
toxin in crops used for food and feed consumption throughout the world (Mishra et al., 2013), it has gained global attention over the last decade and regulatory limits have been set by the European Commission (EC, 2006, 2007), to protect humans from this and other mycotoxin exposure through cereal grain consumption (Regulation EC No. 1881/2006 and EC No. 1126/2007, with a limit of $1,250 \mu \mathrm{g} / \mathrm{kg}$ in unprocessed cereals other than durum wheat, oats and maize).

The presence of DON is closely linked to rainy climates or hot and humid conditions during the phenological phases between earing and milk ripeness (Van der FelsKlerx et al., 2013). A rainy event, close to flowering, accounts for more than $70 \%$ of the DON contamination present at the harvest (Hooker et al., 2002). Moreover, $F$. graminearum has been found to dominate in regions with warm and humid conditions, whereas F. culmorum has been associated with cool, wet and humid conditions (Bottalico and Perrone, 2002).

The most important strategies to minimise DON occurrence in winter wheat, in areas characterised by a probable high FHB infection, are related to the use of preventive agronomic practices to reduce the pathogen inocula in field trough crop rotation and soil tillage, and to the use of resistant varieties, following an integrated approach that addresses all the possible risk factors (Blandino et al., 2012). However, in climatic conditions conductive to fungal diseases, the above preventive measures could be insufficient, and direct control, through the use of fungicide application, is necessary (Mesterházy et al., 2003; Ransom and McMullen, 2008). Thus, in temperate areas, fungicide application from heading to anthesis is one of the most widely diffused practices in order to minimise the negative effects of these fungal diseases on wheat (Mesterházy et al., 2003; Ransom and McMullen, 2008).

Fungicides containing triazole, imidazole or triazolinthione active ingredients, which inhibit the biosynthesis of ergosterol, have proved to be the most active molecules for the control of FHB infection and the consequent DON contamination (Paul et al., 2008), as they lead to a clear increase in grain yield, when the disease is present.

Unfortunately, DON is only one of the approximately 400 mycotoxins known to date (Berthiller et al., 2007). Moreover, a very limited number of these mycotoxins is subject to legislation and regular monitoring. As far as cereals are concerned, aflatoxins, fumonisins, deoxynivalenol (DON), zearalenone (ZEA) and ochratoxin A (OTA) are those most often analysed (Binder, 2007). For these reasons, the other mycotoxins, which till now have not received detailed scientific attention, are commonly indicated as 'novel' or 'emerging' mycotoxins (Streit et al., 2013). There is therefore an urgent need to acquire data on the presence and diffusion of these emerging mycotoxins in field crops, in relationship to different climatic conditions, in order to establish possible maximum limits. It is also important to investigate the effect of the agronomic strategies that are commonly applied to control DON on the occurrence of the other mycotoxins, produced by other Fusarium spp. or genus.

Therefore, in order to set up the Best Management Practices to minimise the risk of mycotoxins in cereal, it is of great importance to assess the efficacy of fungicide applications to control also the emerging mycotoxins, taking into account different climatic conditions. Moreover, because of the differences in fungicide sensitivity of the different Fusarium spp. or of the other ear-colonising saprophytic fungi, antagonist to Fusarium spp., such as Microdochium spp. or Alternaria alternata (Müllenborn et al., 2007), it is also necessary to verify whether there could be an unbalanced modification within the mycoflora of wheat ears, which could lead to an increase in some mycotoxins. This assessment is fundamental to understand, through a holistic approach, the effect of a fungicide application on wheat sanity to control FHB and DON contamination.

In the present study, four field experiments have been conducted in North West Italy, over a period of 2 growing seasons, in order to evaluate the effect of fungicide application on the contamination of emerging mycotoxins in common winter wheat (Triticum aestivum L.) under naturally-infected field conditions. The aim of this study was therefore to assess and verify, through experiments conducted in different pedo-climatic conditions, whether the fungicide usually applied to control FHB and DON content, could also result in a reduction of the main emerging mycotoxins of winter wheat.

\section{Materials and methods}

\section{Experimental sites and treatments}

Field experiments were carried out, from 2010 to 2012, in 2 growing seasons and in 3 sites in North West Italy:

- Experiment A: at Cigliano ( $45^{\circ} 18^{\prime} \mathrm{N}, 8^{\circ} 01^{\prime} \mathrm{E}$; altitude of $237 \mathrm{~m}$ ) in the 2010-2011 growing season, in a sandy loam soil, TypicHapludalfs (USDA classification);

- Experiments B and D: at Poirino (44. 54' N, $7^{\circ} 24^{\prime}$ E; altitude $262 \mathrm{~m}$ ) in the 2010-2011 and 2011-2012 growing seasons, respectively, in a sandy silty loam soil, TypicUdifluvents (USDA classification);

- Experiment C: at Carmagnola ( $44^{\circ} 50^{\prime} \mathrm{N}, 7^{\circ} 40^{\prime} \mathrm{E}$; altitude $245 \mathrm{~m}$ ) in the 2011-2012 growing season, in a loam soil, TypicUdifluvents (USDA classification).

The wheat cultivars were Generale (Consorzio nazionale sementi, Conselice, Italy) in experiments A and C, Bologna (S.I.S. Società Italiana Sementi, San Lazzaro di Savena, Italy) 
in experiment B, and Aubusson (Limagrain Italia, Busseto, Italy) in experiment $\mathrm{D}$. All the cultivars used are classified as medium susceptible to FHB.

An azole fungicide, prothioconazole [Proline ${ }^{\oplus}$; Bayer, Milano, Italy; emulsifiable concentrate formulation (EC), applied at $0.250 \mathrm{~kg}$ of active ingredient $(\mathrm{AI}) / \mathrm{ha}$ ] or a prothioconazole + tebuconazole mixture [Prosaro ${ }^{\circ}$; Bayer; emulsifiable concentrate formulation (EC), applied at 0.125 $\mathrm{kg}$ (AI)/ha] sprayed at heading [growth stage (GS) 59] (Zadoks et al., 1974) was compared in all the fields with an untreated control, under naturally-infected field conditions. The fungicides were applied at the manufacturer's recommended field rates with a 4 nozzle precision sprayer (Honda Agricultural Sprayer T-Jeet 110/04; Honda Motor Europe, Ltd., London, UK), using a fine mist at a slow walk to ensure an effective coverage. The delivery pressure at the nozzle was $324 \mathrm{KPa}$.

The treatments for each field condition were assigned to experimental units using a completely randomised block design with three replicates. The plot size was $7 \times 2 \mathrm{~m}$. The fields were seeded after an autumn ploughing $(30 \mathrm{~cm})$ and disk harrowing to prepare a proper seedbed, following a previous maize crop for grain. Planting was conducted in $12 \mathrm{~cm}$ wide rows at a seeding rate of 450 seeds $/ \mathrm{m}^{2}$. The weed control was conducted with mesosulfuron-metile, iodosulfuron-metil-sodium and mefenpir-dietile (Hussar Maxx ${ }^{\circ}$; Bayer) at wheat tillering (GS 31). A total of $170 \mathrm{~kg}$ $\mathrm{N} /$ ha was applied to the plots as a granular ammonium nitrate fertiliser, and was split between GS 23, 32 and 45 . The sowing, fungicide application and harvesting data of each experiment are reported in Table 1.

The grain yields were obtained by harvesting the whole plot with a Walter Wintersteiger cereal plot combine-harvester (Ried, Austria). A subsample was taken from each plot to determine grain moisture and test weight (TW). The TW was determined using a Dickey-John GAC2000 grain analysis meter (Dickey-John Europe, Colombes, France), according to the supplied programme. The TW was recorded as $\mathrm{kg} / \mathrm{hl}$. The grain yield results were adjusted to a $130 \mathrm{~g} / \mathrm{kg}$ moisture content. The harvested grains were mixed thoroughly, and $2 \mathrm{~kg}$ grain samples were taken from each plot to analyse the mycotoxin content.

\section{Fusarium Head Blight symptoms}

FHB incidence and severity were recorded for each plot, by carrying out visual evaluations of the disease at the soft dough stage (GS 85). FHB head blight incidence was calculated as the percentage of ears with symptoms when 200 ears per plot were analysed. FHB severity was calculated as the percentage of kernels per ear with symptoms. A scale of 1 to 7 was used in which each numerical value corresponded to a percentage interval of surfaces exhibiting visible symptoms of the disease according to the following schedule: $1=0-5 \%, 2=5-15 \%, 3=15-30 \% ; 4=30-50 \%, 5$ $=50-75 \%, 6=75-90 \%, 7=90-100 \%$ (Parry et al., 1995). The FHB severity scores were converted into percentages of the ear exhibiting symptoms, replacing each score with the mid-point of the interval.

\section{Multi-mycotoxin LC-MS/MS analysis}

A $2 \mathrm{~kg}$ representative sample of grain from each plot was ground using a ZM 200 Ultra Centrifugal Mill (Retsch $\mathrm{GmbH}$, Haan, Germany) fitted with a $1 \mathrm{~mm}$ aperture sieve, and the resulting whole meal was used directly for the extraction. Five g representative sub-samples of the milled material were extracted using $20 \mathrm{ml}$ of a mixture of acetonitrile:water:acetic acid (79:20:1, v/v/v). After extraction, the samples were centrifuged, diluted 1:1 and injected as described in detail by Sulyok et al. (2006). Five replicas of the $5 \mathrm{~g}$ ground wheat samples, free of or with very low levels of the detected mycotoxins, were spiked in order to evaluate the recovery rate of the analytical method for the different mycotoxins. Standards of fungal metabolites were obtained either as gifts from various research groups or from the following commercial sources: Biopure Referenzsubstanzen GmbH (Tulln, Austria), Sigma-Aldrich (Vienna, Austria), Iris Biotech GmbH (Marktredwitz, Germany), Axxora Europe (Lausanne, Switzerland) and LGC Promochem GmbH (Wesel, Germany). The average recovery percentages of the detected fungal metabolites were: $120.0 \%$ for alternariol $(\mathrm{AOH}), 113.9 \%$ for alternariol methyl ether (AME), 80.9\% for aurofusarin (AUR), 100.3\% for beauvericin (BEA), 95.7\% for bikaverin (BIK), 86.3\% for butenolide (BUT), 99.7\% for culmorin (CULM), 103.5\% for decalonectrin (DEC), $112.9 \%$ for DON, $100.2 \%$ for deoxynivalenol-3-glucoside

Table 1. Main trial information on the field experiments conducted on winter wheat in North West Italy in the 2010-2012 period.

$\begin{array}{lllcrr}\text { Experiment } & \text { Growing season } & \text { Site } & \text { Sowing date } & \text { Fungicide application } & \text { Harvest date } \\ \text { A } & 2010-2011 & \text { Cigliano } & \text { 30 October 2010 } & \text { 13 May 2011 } & \text { 1 July } 2011 \\ \text { B } & 2010-2011 & \text { Poirino } & 5 \text { November 2010 } & 6 \text { May 2011 } & 29 \text { June } 2011 \\ \text { C } & 2011-2012 & \text { Carmagnola } & \text { 21 October 2011 } & \text { 23 May 2012 } & 11 \text { July } 2012 \\ \text { D } & 2011-2012 & \text { Poirino } & \text { 24 November 2011 } & \text { 15 May 2012 } & \text { 4 July } 2012\end{array}$


(DON-3G), 110.4\% for 3-acetyldeoxynivalenol (3-ADON), $108.0 \%$ for 15 -acetyldeoxynivalenol (15-ADON), 92.8\% for enniatins (ENNs = ENN A, ENN A 1 , ENN B, ENN B ${ }_{1}$, ENN $B_{2}$ ), 200.1\% for equisetin (EQU), 71.1\% for fusaric acid (FA), 72.0\% for fumonisins $\left(\mathrm{FB}_{1}, \mathrm{FB}_{2}, \mathrm{FB}_{3}\right), 95.7 \%$ for moniliformin (MON), 86.2\% for nivalenol (NIV), $126.8 \%$ for tentoxin (TENT) and $117.0 \%$ for ZEA.

The results of the fungal metabolites concentrations were corrected on the basis of the recovery rate. Detection and quantification were performed with a QTrap 5500 LC-MS/MS System (Applied Biosystems, Foster City, CA, USA), equipped with a TurboIonSpray electrospray ionization (ESI) source and a 1290 Series HPLC System (Agilent, Waldbronn, Germany). Chromatographic separation was performed at $25{ }^{\circ} \mathrm{C}$ on a Gemini ${ }^{\circ} \mathrm{C} 18$ column, $150 \times 4.6 \mathrm{~mm}$ i.d., $5 \mu \mathrm{m}$ particle size, equipped with a $\mathrm{C} 18$ security guard cartridge, $4 \times 3 \mathrm{~mm}$ i.d. (all from Phenomenex, Torrance, CA, USA). The chromatographic and mass spectrometric parameters of the investigated analytes were described by Sulyok et al. (2007) and Malachova et al. (2014). The applied multi-mycotoxin method was previously subjected to proficiency tests (Malachova et al., 2014).

\section{Statistical analysis}

The normal distribution and homogeneity of variances were verified by performing the Kolmogorov-Smirnov normality test and the Levene test, respectively. An analysis of variance (ANOVA) was conducted separately for each experiment in order to evaluate the effect of the fungicide application on grain yield, TW, FHB incidence and severity, and DON contamination, using a completely randomised block design. Moreover, ANOVA was utilised to compare the emerging mycotoxin content, using a completely randomised block design, in which the fungicide treatment was the independent variable and the experiment (different growing seasons and sites) was the random factor. Instead, when the interaction between the fungicide treatment and the experiment was significant, the ANOVA was applied separately for each experiment. The fungal metabolites concentrations were transformed using the $y^{\prime}=\ln (x+1)$ equation to normalise the residuals. The SPSS for Windows, Version 20.0 statistical package (SPSS Inc., Chicago, IL, USA), was used for the statistical analysis.

\section{Results}

\section{Weather conditions}

The two growing seasons showed different meteorological trends from the beginning of the stem elongation stage to harvesting (Table 2). Frequent rainfall occurred in 2011, at the beginning of stem elongation (March) and at the end of ripening (June). Moreover, the rainfall was low close to the anthesis stage (May) in both experiments conducted in the 2010-11 growing season (A and B). Instead, in 2012, rainfall was concentrated close to the end of the stem elongation

Table 2. Total rainfall, rainy days, relative humidity and growing degree days (GDDs) from March to June 2010-2012 in the research sites.

\begin{tabular}{|c|c|c|c|c|c|c|c|}
\hline \multirow[b]{2}{*}{ Growing season } & \multirow[b]{2}{*}{ Month } & \multicolumn{3}{|l|}{ Experiment $A$} & \multicolumn{3}{|l|}{ Experiment $\mathrm{B}$} \\
\hline & & Rainfall (mm) & Rainy days (n) & $\operatorname{GDDs}{ }^{1}\left({ }^{\circ} \mathrm{C} / \mathrm{d}\right)$ & Rainfall (mm) & Rainy days (n) & $\operatorname{GDDs}^{1}\left({ }^{\circ} \mathrm{C} / \mathrm{d}\right)$ \\
\hline \multirow[t]{6}{*}{$2010-2011$} & March & 169 & 9 & 268 & 211 & 12 & 264 \\
\hline & April & 59 & 5 & 474 & 33 & 3 & 467 \\
\hline & May & 30 & 5 & 578 & 47 & 5 & 571 \\
\hline & June & 198 & 14 & 627 & 252 & 17 & 599 \\
\hline & Flowering period ${ }^{2}$ & 6 & 2 & 129 & 0 & 0 & 116 \\
\hline & . & \multicolumn{3}{|l|}{ Experiment $\mathrm{C}$} & \multicolumn{3}{|l|}{ Experiment D } \\
\hline Growing season & Month & Rainfall (mm) & Rainy days (n) & $\operatorname{GDDs}{ }^{1}\left({ }^{\circ} \mathrm{C} / \mathrm{d}\right)$ & Rainfall (mm) & Rainy days (n) & $\operatorname{GDDs}^{1}\left({ }^{\circ} \mathrm{C} / \mathrm{d}\right)$ \\
\hline \multirow[t]{5}{*}{$2011-2012$} & March & 20 & 1 & 347 & 36 & 3 & 394 \\
\hline & April & 148 & 13 & 365 & 160 & 14 & 370 \\
\hline & May & 147 & 6 & 539 & 123 & 7 & 538 \\
\hline & June & 19 & 2 & 674 & 38 & 6 & 680 \\
\hline & Flowering period ${ }^{2}$ & 106 & 4 & 124 & 61 & 3 & 113 \\
\hline
\end{tabular}


and anthesis in both experiments (C and D), and lower growing degree days were recorded than those of 2011.

\section{Fusarium Head Blight symptoms}

The incidence and severity of the FHB symptoms recorded during the visual evaluations were higher in the 20112012 growing season than in the 2010-2011 one (Table 3). According to the weather conditions during the growing season, the mean FHB incidence and severity of the untreated control were 63.0 and $14.4 \%$, respectively, in experiments C and D (growing season 2011-2012), while these parameters were 8.7 and $1.4 \%$, respectively, in the experiments carried out in 2010-2011 growing season. ANOVA showed a significant effect of the fungicide treatments on FHB incidence and severity in all the experiments $(P<0.05)$, except experiment $\mathrm{B}$. Considering all the experiments, the azole application at heading significantly reduced the FHB incidence and severity compared to the untreated control, with an average reduction of 66 and $84 \%$, for the two parameters, respectively.

\section{Yield and yield components}

ANOVA showed a significant effect of fungicide treatment on grain yield in all the experiments $(P<0.05)$, except experiment A (Table 3 ). In these experiments, the fungicide application significantly increased the yield by $12 \%$ compared to the untreated control. The fungicide treatment only significantly increased the test weight parameter by $2.5 \mathrm{~kg} / \mathrm{hl}$ in experiment $\mathrm{B}$, but a similar trend was observed in all the other experiments.

\section{Mycotoxin contamination}

The dilute-and-shoot multi-mycotoxin LC-MS/MS method was able to detect about 20 fungal metabolites: ENNs (ENN A, ENN A 1 , ENN B, ENN B 1 , ENN B ${ }_{2}$ ), AUR, MON, EQU, DON, DON-3G, CULM, BIK, BEA, fumonisins $\left(\mathrm{FB}_{1}, \mathrm{FB}_{2}\right.$, $\mathrm{FB}_{3}$ ), FA, 3-ADON, 15-ADON, NIV, ZEA, DEC, BUT, TENT, AOH and AME.

The most abundant fungal metabolites were DON, DON$3 \mathrm{G}$ and CULM, with an average contamination in the untreated control of 1,360, 367 and $875 \mu \mathrm{g} / \mathrm{kg}$, respectively, in the growing season with the highest disease pressure (2011-2012). Instead, in the growing season with the lowest disease pressure (2010-2011), DON, DON-3G and CULM were present with an average contamination in the untreated control of 72, 32 and $61 \mu \mathrm{g} / \mathrm{kg}$, respectively. Since a significant 'experiment $\times$ fungicide treatment' interaction was recorded by ANOVA for these three mycotoxins, which are produced by the same Fusarium species ( $F$. graminearum and F. culmorum), the 4 experiments were statistically analysed separately and the results are reported in Figure 1. All these mycotoxins were significantly reduced by the fungicide application $(P<0.01$ for experiment $C$ and $P<0.05$ for experiment $\mathrm{D}$ ), but only in the experiments conducted in the growing season with the highest FHB attack (2011-2012). In these experiments, on average, the fungicide treatment significantly reduced the DON, DON3G and CULM contents by 72,67 and 70\%, respectively, compared to the untreated control.

On the other hand, ANOVA showed a significant effect of fungicide application on the occurrence of ENNs, AUR, MON, TENT and EQU, while the interaction between the fungicide treatment and the experiment was never

Table 3. Effect of fungicide application on Fusarium Head Blight (FHB) incidence and severity, grain yield and test weight of winter wheat. The field experiments ${ }^{1}$ (A, B, C and D) were conducted in North West Italy in the 2010-2012 period.

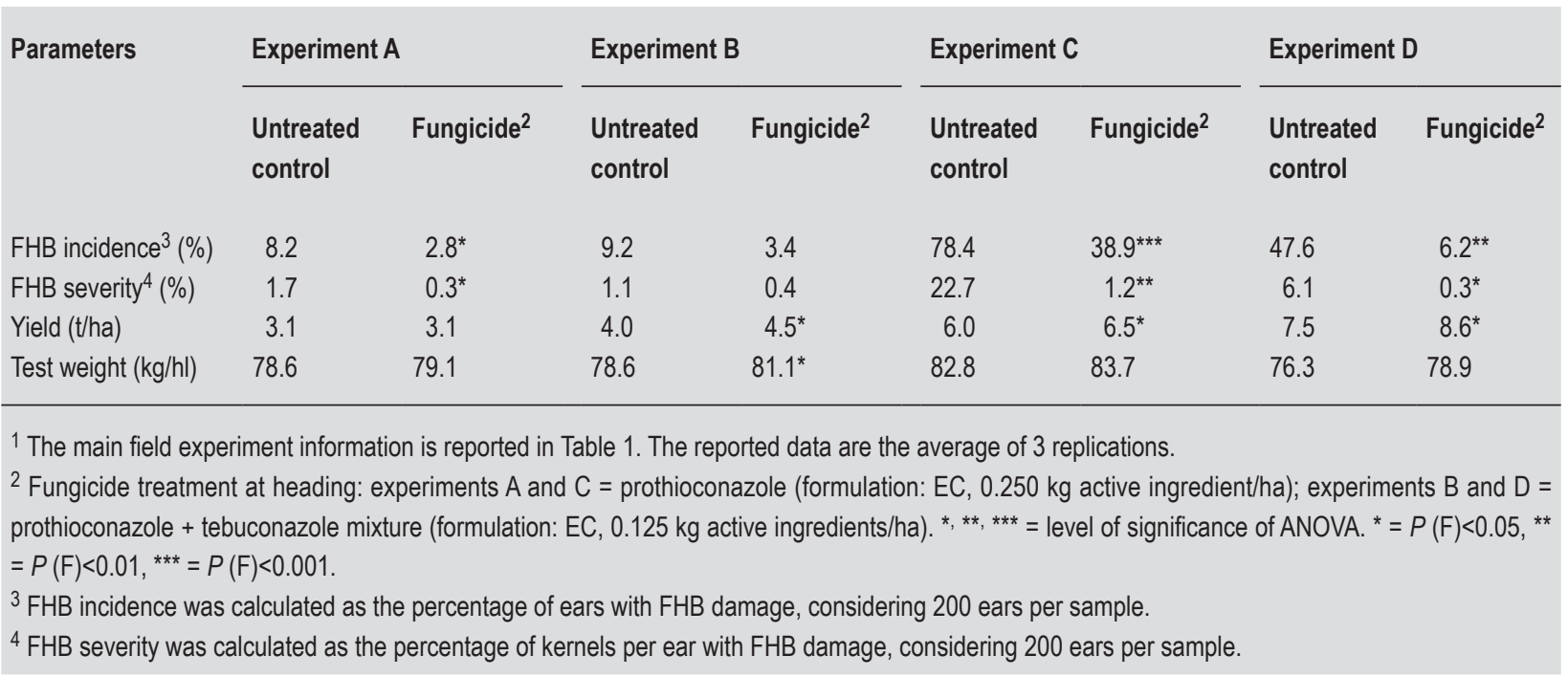




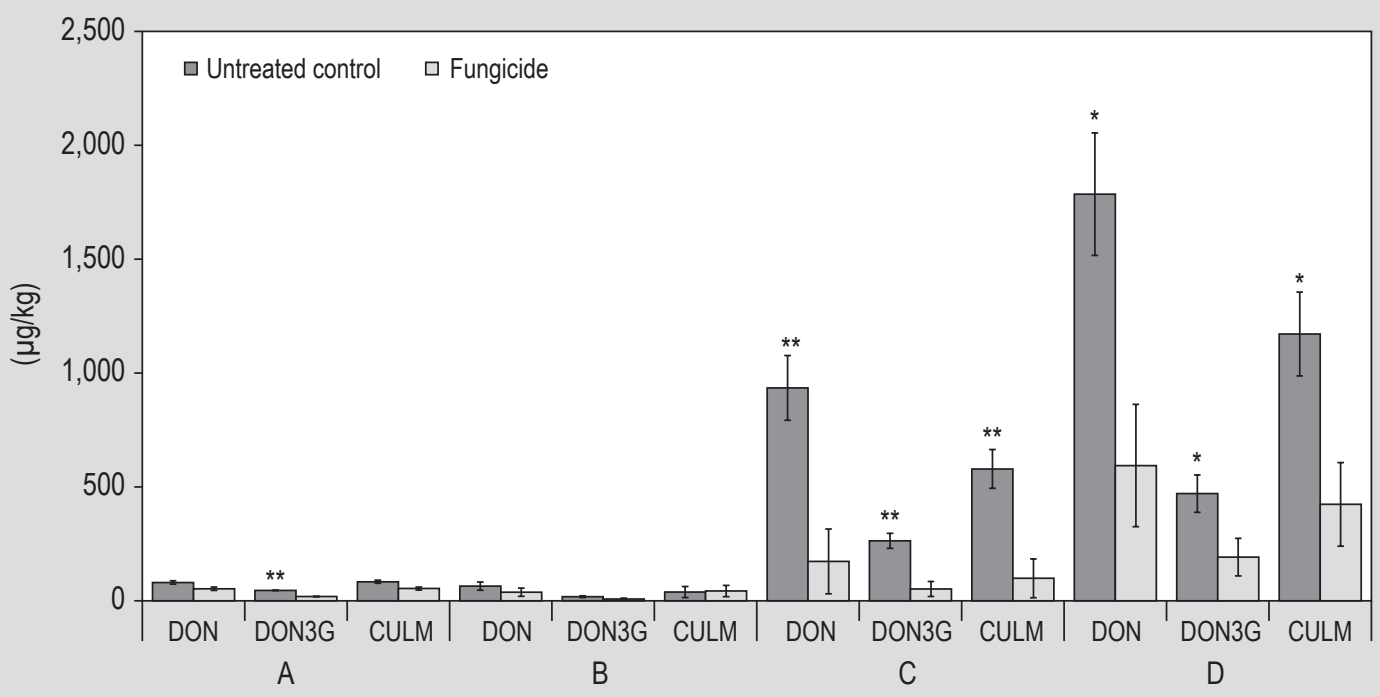

Figure 1. Effect of fungicide application on deoxynivalenol (DON), deoxynivalenol-3-glucoside (DON-3G) and culmorin (CULM) contaminations in 4 field experiments carried out in North West Italy in the 2010-2012 period. The main field experiment information is reported in Table 1. $P(F)=$ level of significance of ANOVA; ${ }^{*} P<0.05,{ }^{*} P<0.01$.

Table 4. Effect of fungicide application on enniatins (ENNs), aurofusarin (AUR), moniliformin (MON), tentoxin (TENT) and equisetin (EQU) contamination ${ }^{1,2}$ in winter wheat grain. The field experiments were conducted in North West Italy in the 2010-2012 period.

\begin{tabular}{|c|c|c|c|c|c|c|c|c|c|c|c|}
\hline \multirow[t]{2}{*}{ Source of variation } & \multirow[t]{2}{*}{ Factor } & \multicolumn{2}{|c|}{ ENNs } & \multicolumn{2}{|c|}{ AUR } & \multicolumn{2}{|c|}{ MON } & \multicolumn{2}{|c|}{ TENT } & \multicolumn{2}{|l|}{ EQU } \\
\hline & & $\mathrm{T}$ & $\begin{array}{l}N \\
(\mu g / k g)\end{array}$ & $T$ & $\begin{array}{l}N \\
(\mu g / k g)\end{array}$ & $T$ & $\begin{array}{c}N \\
(\mu \mathrm{g} / \mathrm{kg})\end{array}$ & $T$ & $\begin{array}{l}N \\
(\mu \mathrm{g} / \mathrm{kg})\end{array}$ & $T$ & $\begin{array}{l}\mathrm{N} \\
(\mu \mathrm{g} / \mathrm{kg})\end{array}$ \\
\hline \multirow[t]{4}{*}{ Experiment ${ }^{3}$} & $A$ & 3.7 & 51 & 4.1 & 66 & 1.3 & 4 & 0.91 & 1.61 & 0.28 & 0.58 \\
\hline & $\mathrm{B}$ & 3.4 & 73 & 1.9 & 7 & 2.1 & 17 & 1.25 & 2.72 & 0.04 & 0.04 \\
\hline & $\mathrm{C}$ & 4.0 & 69 & 2.7 & 22 & 2.8 & 25 & 1.19 & 2.51 & 0.29 & 0.40 \\
\hline & $D$ & 4.8 & 144 & 4.1 & 69 & 3.8 & 49 & 2.13 & 8.13 & 0.29 & 0.42 \\
\hline \multirow[t]{3}{*}{ Treatment $^{4}$} & Untreated control & 4.6 & 127 & 3.9 & 62 & 3.0 & 32 & 1.65 & 5.20 & 0.42 & 0.72 \\
\hline & Fungicide & 3.4 & 46 & 2.6 & 21 & 2.1 & 16 & 1.14 & 2.57 & 0.06 & 0.06 \\
\hline & $P(\mathrm{~F})^{5}$ & * & & * & & * & & $* *$ & & * & \\
\hline Treatment $\times$ Experiment & $P(\mathrm{~F})^{5}$ & NS & & NS & & NS & & NS & & NS & \\
\hline
\end{tabular}

\footnotetext{
${ }^{1}$ The reported values of the experiment factor are based on 6 replications ( 2 treatment $\times 3$ repetitions), while the values of the treatment factor are based on 12 replications ( 4 experiment $\times 3$ repetitions).

2 The reported mycotoxin contamination means are transformed $\left[T ; y^{\prime}=\ln (x+1)\right]$ and not transformed $(N)$ values.

${ }^{3}$ The main field experiment information is reported in Table 1.

${ }^{4}$ Fungicide treatment at heading: experiments $A$ and $C=$ prothioconazole (formulation: $E C, 0.250 \mathrm{~kg}$ active ingredient/ha); experiments $B$ and $D=$ prothioconazole + tebuconazole mixture (formulation: $E C, 0.125 \mathrm{~kg}$ active ingredients $/ \mathrm{ha}$ ).

${ }^{5} P(\mathrm{~F})=$ level of significance of ANOVA. ${ }^{*}=P(\mathrm{~F})<0.05,{ }^{*}=P(\mathrm{~F})<0.01, \mathrm{NS}=$ not significant.
}

significant (Table 4). On average, the fungicide application significantly reduced the ENNs (from 127 to $46 \mu \mathrm{g} / \mathrm{kg}$, $P=0.036$ ), AUR (from 62 to $21 \mu \mathrm{g} / \mathrm{kg}, P=0.032$ ), MON (from 32 to $16 \mu \mathrm{g} / \mathrm{kg}, P=0.036$ ) TENT (from 5.20 to $2.57 \mu \mathrm{g} / \mathrm{kg}$, $P=0.002$ ) and EQU (from 0.72 to $0.06 \mu \mathrm{g} / \mathrm{kg}, P=0.050$ ) contents. Compared to the untreated control, the average reduction recorded was $64,66,50,51$ and $92 \%$ for ENNs, AUR, MON, TENT and EQU, respectively.
Fumonisins, FA, ZEA and NIV were found at low contamination levels, while ANOVA showed significant 'experiment $\times$ fungicide' interactions for DON, DON3G and CULM. The effect of fungicide application on fumonisin, FA, ZEA and NIV contents is shown in Table 5 for each experiment. Fumonisin and FA were significantly reduced after the fungicide application $(P<0.05)$ in experiment $\mathrm{D}$, which was conducted in the growing 
Table 5. Effect of fungicide application on fungal metabolites contamination in winter wheat grain. The field experiments ${ }^{1}$ (A, B, $C$ and D) were conducted in North West Italy in the 2010-2012 period.

\begin{tabular}{|c|c|c|c|c|c|c|c|c|}
\hline \multirow{2}{*}{$\begin{array}{l}\text { Fungal } \\
\text { metabolites }^{2}\end{array}$} & \multicolumn{2}{|l|}{ Experiment $\mathrm{A}$} & \multicolumn{2}{|l|}{ Experiment $B$} & \multicolumn{2}{|l|}{ Experiment $\mathrm{C}$} & \multicolumn{2}{|l|}{ Experiment $D$} \\
\hline & $\begin{array}{l}\text { Untreated } \\
\text { control }(\mu \mathrm{g} / \mathrm{kg})\end{array}$ & $\begin{array}{l}\text { Fungicide }^{3} \\
(\mu \mathrm{g} / \mathrm{kg})\end{array}$ & $\begin{array}{l}\text { Untreated } \\
\text { control }(\mu \mathrm{g} / \mathrm{kg})\end{array}$ & $\begin{array}{l}\text { Fungicide }^{3} \\
(\mu \mathrm{g} / \mathrm{kg})\end{array}$ & $\begin{array}{l}\text { Untreated } \\
\text { control }(\mu \mathrm{g} / \mathrm{kg})\end{array}$ & $\begin{array}{l}\text { Fungicide }^{3} \\
(\mu \mathrm{g} / \mathrm{kg})\end{array}$ & $\begin{array}{l}\text { Untreated } \\
\text { control }(\mu \mathrm{g} / \mathrm{kg})\end{array}$ & $\begin{array}{l}\text { Fungicide }^{3} \\
(\mu \mathrm{g} / \mathrm{kg})\end{array}$ \\
\hline FB & 5.58 & 8.11 & 6.24 & 9.77 & 5.73 & 8.69 & 12.81 & $8.82^{*}$ \\
\hline FA & $<L O Q$ & $<L O Q$ & 9.99 & $<L O Q$ & 5.24 & $<L O Q$ & 16.78 & $3.30^{*}$ \\
\hline BEA & 0.63 & 0.48 & 1.45 & 0.63 & 0.11 & 0.04 & 0.31 & 0.16 \\
\hline BIK & $<L O Q$ & $<L O Q$ & 2.70 & 1.84 & $<L O Q$ & $<L O Q$ & $<L O Q$ & $<L O Q$ \\
\hline ZEA & 1.32 & $<\mathrm{LOQ}^{*}$ & 0.71 & $<L O Q$ & 1.60 & $<L O Q$ & 4.38 & $0.52^{*}$ \\
\hline NIV & 0.75 & $<L O Q$ & $<L O Q$ & $<L O Q$ & 0.68 & $<L O Q$ & 1.13 & $<L O Q$ \\
\hline 3-ADON & $<L O Q$ & $<L O Q$ & $<L O Q$ & $<L O Q$ & 6.67 & $<L O Q$ & 9.84 & 5.06 \\
\hline 15-ADON & $<L O Q$ & $<L O Q$ & $<L O Q$ & $<L O Q$ & $<L O Q$ & $<L O Q$ & $<L O Q$ & $<L O Q$ \\
\hline BUT & 3.33 & 1.98 & $<L O Q$ & $<L O Q$ & 5.48 & $<L O Q$ & 6.11 & 3.10 \\
\hline DEC & $<L O Q$ & $<L O Q$ & $<L O Q$ & $<L O Q$ & $<L O Q$ & $<L O Q$ & 1.29 & 0.89 \\
\hline $\mathrm{AOH}$ & 2.68 & 1.46 & $<L O Q$ & $<L O Q$ & 0.28 & $<L O Q$ & $<L O Q$ & $<L O Q$ \\
\hline AME & 0.53 & $<L O Q$ & $<L O Q$ & $<L O Q$ & $<L O Q$ & $<L O Q$ & 0.13 & $<L O Q$ \\
\hline
\end{tabular}

season with the highest FHB disease pressure (2011-2012). Moreover, ZEA was significantly reduced with the fungicide application $(P<0.05)$ in experiments A and D. As far as FA, ZEA and NIV are concerned, the fungicide application on average reduced their contents in the experiments in which no significant differences in FHB attack were observed, in comparison to the untreated control. On the other hand, fumonisin content was not affected by the azole application in experiments $\mathrm{A}, \mathrm{B}$ and $\mathrm{C}$.

The other fungal metabolites (BIK, BEA, 3-ADON, 15$A D O N, D E C, B U T, A O H$ and AME) were only found in a few cases in traces, but mainly in the untreated plots (Table 5). A similar contamination reduction trend was also observed for these mycotoxins, after the fungicide application.

\section{Discussion}

The findings of this research confirm that the application of azole fungicides could contribute to control FHB in areas characterised by a probable high infection and under climatic conditions that favour fungal diseases. These results are in agreement with several other experiments (Edwards et al., 2001; Matthies and Buchenauer, 2000; Menniti et al., 2003; Paul et al., 2008) that have proved the effectiveness of fungicides containing triazole or triazolinthione in the control of FHB infection. In particular, among the most recent fungicides, the active ingredient prothioconazole has confirmed its high capacity to reduce DON contamination in cereal grain (Haidukowski et al., 2012).

Since the field experiments were conducted over two years characterised by different meteorological trends, the collected data also show that the significant efficacy of the fungicide application on DON contamination is closely linked to the pressure level of the disease. In a previous work conducted in NW Italy (Blandino et al., 2011), DON contamination was reduced by the fungicide to a greater extent in the low risk agronomic and environmental conditions than in the high risk ones.

As regards the contamination levels, the obtained results show that mycotoxins such as DON, DON-3G and CULM, which are mainly produced by $F$. culmorum and F. graminearum, were the most abundant mycotoxins in the environmental conditions of the considered field experiments. The contamination of all these mycotoxins 
was higher, especially in the growing season with the highest disease pressure (2011-2012), thus confirming the close link between these Fusarium spp. and FHB. DON-3G, one of the several masked mycotoxins, is a phase II plant metabolite of the Fusarium mycotoxin DON (Berthiller et al., 2013) which could be hydrolysed in the digestive tract of mammals, thus contributing to the total dietary DON exposure of individuals (Berthiller et al., 2011). Moreover, data reported by Lemmens et al. (2005) and by Cirlini et al. (2014) support the hypothesis that, in resistant wheat lines, most of the DON is converted to DON-3G and this conversion mechanism actually seems to be related to their resistance to FHB. As far as the occurrence and the relationship between DON and DON-3G are concerned, the present results are supported by data from other studies which show that the DON-3G/DON ratio varies in relation to the year and genotype and can reach levels of 29\% (Berthiller et al., 2009) or even 70\% (De Boevre et al., 2012). On the other hand, the relationship between the DON and CULM contents reported in the present work is in agreement with data obtained by Ghebremeskel and Langseth (2000), which indicate that CULM and various hydroxy-culmorins (5- and 15-hydroxy-culmorin) are present in the same concentration ranges as DON in naturally contaminated grain. Moreover, although CULM and hydroxy-culmorins have shown low toxicity in several in vitro assays (Pedersen and Miller, 1999), they may contribute to enhancing the toxicity of DON (Ghebremeskel and Langseth, 2000).

The obtained results are also in agreement with several studies that show that: (1) Fusarium culmorum and F. graminearum are potent colonisers of wheat tissue that can compete and reduce the growth of other Fusarium spp. (Jones et al., 1997) or other toxigenic fungi such as Alternaria spp. (Müller et al., 2012); (2) in temperate areas, DON is the most prevalent mycotoxin in wheat (Mishra et al., 2013).

As far as the effectiveness of fungicide application to control these mycotoxins is concerned, on average, azole applications at heading have reduced the DON, DON$3 \mathrm{G}$ and CULM contents by about $70 \%$, compared to an untreated control. On the other hand, although the ENNs, AUR, MON, EQU, BIK, BEA, fumonisins, FA, 3-ADON, NIV, ZEA, DEC, BUT, TENT, AOH and AME have been detected at lower levels than the DON, DON-3G and CULM, the presence of some of them have been reported for the first time in the current study in naturally infected winter wheat from Southern Europe. The levels of MON, BEA and NIV are comparable to those reported by Jestoi et al. (2004), Uhlig et al. $(2007,2013)$ and Lindblad et al. (2013). ENNs have been detected at comparable or slightly lower levels, depending on which growing season was considered in the previously cited studies, while AUR, ZEA, EQU, BUT and 3-ADON are present at lower values than those found by Uhlig et al. (2013). The Alternaria toxins,
$\mathrm{AOH}$ and $\mathrm{AME}$, are instead present at lower values than those reported by Müller and Korn (2013) and Uhlig et al. (2013), while tentoxin, although only present in traces, has been found for the first time in naturally contaminated winter wheat. Finally, fumonisins, FA, BIK and DEC have also been detected in traces and, until now, no evidence has been reported about their occurrence in naturally contaminated winter wheat.

As far as the effectiveness of a fungicide application to control these mycotoxins is concerned, on average, in the different field experiments conducted in the current study, the fungicide treatment has significantly reduced, by more than $50 \%$, the occurrence of the emerging mycotoxins. The mycotoxins detected in traces, were also mainly present in the untreated plots and a similar contamination reduction trend was observed after the fungicide application.

The FHB of wheat is mainly caused by a complex of Fusarium species, including F. graminearum, F. culmorum, Fusarium avenaceum, Fusarium poae and Fusarium sporotrichioides (Parry et al., 1995), and all of these Fusarium species are able to produce a wide range of mycotoxins. For this reason, it is necessary to take into account the distribution and predominance of FHB pathogens and the consequently produced mycotoxins which vary from year to year and which are closely linked to environmental and climatic factors (Doohan et al., 2003). The competitive interaction that occurs between the application of different fungicides classes and the fungal species involved in FHB in wheat has been well documented in literature. The strobilurin fungicides have shown poor efficacy against FHB caused by toxigenic Fusarium spp., such as F. culmorum, F. avenaceum and F. graminearum, while they have ensured a significant reduction in $M$. nivale, a non-toxigenic pathogen which, unlike the Fusarium species, despite being involved in the symptomatology of the disease, is not able to synthesize DON (Edwards, 2004; Simpson et al., 2001). Moreover, during in vitro studies, strobilurins have been shown to induce the production of DON (D'Mello et al., 2001), while during field studies it emerged that these molecules do not seem to have a direct effect on the synthesis of the toxin (Pirgozliev et al., 2002). In these previous cases, the increase in DON contamination was probably due to a reduction in the presence of $M$. nivale, which resulted in an increase in the DON-toxigenic Fusarium species (Pirgozliev et al., 2003).

In the field experiments analysed in the present study, mycotoxins produced by several different Fusarium spp. have been detected together with traces of those produced by Alternaria spp. (Table 6). The present results show a similar contamination reduction trend after the fungicide application, not only for DON but also for almost all the mycotoxins present at different contamination levels. 
Table 6. Main producing species of mycotoxins detected in the wheat samples.

\begin{tabular}{|c|c|c|c|c|c|}
\hline Mycotoxin & Produced by & References & Mycotoxin & Produced by & References \\
\hline Deoxynivalenol & $\begin{array}{l}\text { Fusarium graminearum; } \\
\text { Fusarium culmorum }\end{array}$ & $\begin{array}{l}\text { Bottalico and Perrone, } \\
\text { 2002; Rasmussen et al., } \\
2012\end{array}$ & $\begin{array}{l}\text { Alternariol methyl } \\
\text { ether }\end{array}$ & A. alternata & $\begin{array}{l}\text { Müller and Korn, } \\
\text { 2013; Prelle et al., } \\
2013\end{array}$ \\
\hline $\begin{array}{l}\text { Deoxynivalenol-3- } \\
\text { glucoside }\end{array}$ & $\begin{array}{l}\text { Phase II plant metabolite } \\
\text { of deoxynivalenol } \\
\text { ('masked mycotoxin') }\end{array}$ & $\begin{array}{l}\text { Berthiller et al., 2013; De } \\
\text { Boevre et al., } 2013\end{array}$ & $\begin{array}{l}\text { 3/15-acetyl- } \\
\text { deoxynivalenol }\end{array}$ & $\begin{array}{l}\text { Phase I plant metabolite } \\
\text { of deoxynivalenol } \\
\text { ('masked mycotoxin') }\end{array}$ & $\begin{array}{l}\text { Berthiller et al., 2013; } \\
\text { De Boevre et al., } \\
2013\end{array}$ \\
\hline Culmorin & $\begin{array}{l}\text { F. graminearum; } \\
\text { F. culmorum }\end{array}$ & $\begin{array}{l}\text { Pedersen and Miller, 1999; } \\
\text { Ghebremeskel and } \\
\text { Langseth, 2000; Streit et } \\
\text { al., 2013; }\end{array}$ & Nivalenol & $\begin{array}{l}\text { F. graminearum; } \\
\text { F. culmorum }\end{array}$ & $\begin{array}{l}\text { Bottalico and Perrone, } \\
\text { 2002; Lindblad et } \\
\text { al., } 2013\end{array}$ \\
\hline $\begin{array}{l}\text { 5/15-hydroxy- } \\
\text { culmorin }\end{array}$ & $\begin{array}{l}\text { F. graminearum; } \\
\text { F. culmorum }\end{array}$ & $\begin{array}{l}\text { Pedersen and Miller, 1999; } \\
\text { Ghebremeskel and } \\
\text { Langseth, 2000; Streit et } \\
\text { al., } 2013\end{array}$ & Zearalenone & $\begin{array}{l}\text { F. graminearum; } \\
\text { F. culmorum }\end{array}$ & $\begin{array}{l}\text { Bottalico and Perrone, } \\
\text { 2002; Lindblad et } \\
\text { al., } 2013\end{array}$ \\
\hline Enniatins & Fusarium avenaceum & $\begin{array}{l}\text { Bottalico and Perrone, } 2002 \\
\text { Lindblad et al., } 2013\end{array}$ & Butenolide & $\begin{array}{l}\text { F. graminearum; } \\
\text { F. culmorum }\end{array}$ & $\begin{array}{l}\text { Wang et al., 2009; } \\
\text { Streit et al., } 2013\end{array}$ \\
\hline Aurofusarin & $\begin{array}{l}\text { F. avenaceum; } \\
\text { F. graminearum; } \\
\text { F. culmorum }\end{array}$ & $\begin{array}{l}\text { Uhlig et al., } 2006 \\
\text { Streit et al., } 2013\end{array}$ & Decalonectrin & $\begin{array}{l}\text { F. graminearum; Fusarium } \\
\text { sporotrichioides }\end{array}$ & $\begin{array}{l}\text { McCormick et al., } \\
2004\end{array}$ \\
\hline Moniliformin & $\begin{array}{l}\text { F. avenaceum; Fusarium } \\
\text { subglutinans; } \\
\text { F. proliferatum }\end{array}$ & $\begin{array}{l}\text { Jestoi, 2008; Lindblad et } \\
\text { al., } 2013\end{array}$ & Fumonisins & $\begin{array}{l}\text { Fusarium verticillioides; } \\
\text { F. proliferatum }\end{array}$ & $\begin{array}{l}\text { Palacios et al., } \\
\text { 2011; Scott, 2012; } \\
\text { Cendoya et al., } 2014\end{array}$ \\
\hline Equisetin & Fusarium equiseti & $\begin{array}{l}\text { Wheeler et al., 1999; Streit } \\
\text { et al., } 2013\end{array}$ & Fusaric acid & $\begin{array}{l}\text { F. verticillioides; } \\
\text { F. proliferatum }\end{array}$ & $\begin{array}{l}\text { Bacon et al., 1996; } \\
\text { Shimshoni et al., } \\
2013\end{array}$ \\
\hline Tentoxin & Alternaria alternata & $\begin{array}{l}\text { Prelle et al., 2013; } \\
\text { Shimshoni et al., } 2013\end{array}$ & Beauvericin & $\begin{array}{l}\text { F. avenaceum; Fusarium } \\
\text { subglutinans; } \\
\text { F. proliferatum }\end{array}$ & $\begin{array}{l}\text { Jestoi, 2008; Lindblad } \\
\text { et al., } 2013\end{array}$ \\
\hline Alternariol & A. alternata & $\begin{array}{l}\text { Müller and Korn, 2013; } \\
\text { Prelle et al., } 2013\end{array}$ & Bikaverin & F. verticillioides & Lazzaro et al., 2012 \\
\hline
\end{tabular}

Although the present study was not set up to analyse the infection and development of fungal community in detail, the collected data, considering the final level of several fungal metabolites, show that the applied azole treatments are able to reduce both FHB infection caused by Fusarium spp. and the occurrence of other saprophytic fungi antagonist to Fusarium spp., such as Alternaria alternata. These results are supported by Bertelsen et al. (2001) and Müllenborn et al. (2007), which reported that, although the growth reduction of Alternaria alternata obtained through the use of strobilurins was stronger than that obtained through the use of triazoles, these last cited fungicides were also able to inhibit the mycelia growth of this saprophyte fungus. Thus, no evidence has emerged of an increase in any mycotoxin as a consequence of a modification in the fungal community, related to the different control capacity of the azole fungicides.
In conclusion, the results of these experiments, obtained under naturally-infected field conditions and conducted over two growing seasons characterised by extremely different meteorological trends and FHB pressures, underline that the application of an azole fungicide at heading (prothioconazole and tebuconazole), the most common FHB and DON contamination control practice applied in temperate areas, also results in a consistent and clear reduction in the other winter wheat mycotoxins.

In order to reconsider wheat protection programmes, and to take into account emerging mycotoxins, a fungicide treatment, applied to control fungal ear infection, could also contribute to improving the global sanity of this crop. Therefore, since Good Agricultural Practices require an integrated approach that addresses all the possible risk factors in order to prevent mycotoxin contamination, the role of other practices, which have proved to have a significant effect on DON control, such as soil tillage, 
crop rotation and cultivar susceptibility to FHB, need to be considered to verify their effectiveness on emerging mycotoxins.

\section{Acknowledgements}

The authors would like to thank Federico Marinaccio, Valentina Sovrani and Francesca Vanara for their precious help and cooperation in the laboratory and field work. The research was conducted with the financial support of the Italian Ministry of Agriculture, Food and Forestry (MiPAAF), as a part of the MICOPRINCEM interregional project. The LC-MS/MS system was funded by the Federal Country Lower Austria and co-financed by the European regional development fund of the European Union.

\section{References}

Bacon, C.W., Porter, J.K. and Norred, W.P., 1996. Production of fusaric acid by Fusarium species. Applied and Environmental Microbiology 62: 4039-4043.

Bertelsen, J.R., De Neergaard, E. and Smedegaard-Petersen, V., 2001. Fungicidal effects of azoxystrobin and epoxiconazole on phyllosphere fungi, senescence and yield of winter wheat. Plant Pathology 50: 190-205.

Berthiller, F., Crews, C., Dall'Asta, C., De Saeger, S., Haesaert, G., Karlovsky, P., Oswald, I.P., Walburga, S., Gerrit, S. and Stroka, J., 2013. Masked mycotoxins: a review. Molecular Nutrition and Food Research 57: 165-186.

Berthiller, F., Dall'Asta, C., Corradini, R., Marchelli, R., Sulyok, M., Krska, R., Adam, G. and Schuhmacher, R., 2009. Occurrence of deoxynivalenol and its 3-b-D-glucoside in wheat and maize. Food Additives and Contaminants Part A 26: 507-511.

Berthiller, F., Krska, R., Domig, K. J., Kneifel, W., Juge, N., Schuhmacher, R. and Adam, G., 2011. Hydrolytic fate of deoxynivalenol-3-glucoside during digestion. Toxicology Letters 206: 264-267.

Berthiller, F., Sulyok, M., Krska, R. and Schuhmacher, R., 2007. Chromatographic methods for the simultaneous determination of mycotoxins and their conjugates in cereals. International Journal of Food Microbiology 119: 33-37.

Binder, E.M., 2007. Managing the risk of mycotoxins in modern feed production. Animal Feed Science and Technology 133: 149-166.

Blandino, M., Haidukowski, M., Pascale, M., Plizzari, L., Scudellari, D. and Reyneri, A., 2012. Integrated strategies for the control of Fusarium head blight and deoxynivalenol contamination in winter wheat. Field Crops Research 133: 139-149.

Blandino, M., Pascale, M., Haidukowski, M. and Reyneri, A., 2011. Influence of agronomic conditions on the efficacy of different fungicides applied to wheat at heading: effect on flag leaf senescence, Fusarium head blight attack, grain yield and deoxynivalenol contamination. Italian Journal of Agronomy 4: 204-211.

Bottalico, A. and Perrone, G., 2002. Toxigenic Fusarium species and mycotoxins associated with head blight in small-grain cereals in Europe. European Journal of Plant Pathology 108: 611-624.
Cendoya, E., Monge, M.P., Palacios, S.A., Chiacchiera, S.M., Torres, A.M., Farnochi, M.C. and Ramirez, M.L., 2014. Fumonisin occurrence in naturally contaminated wheat grain harvested in Argentina. Food Control 37: 56-61.

Champeil, A., Dore, T. and Fourbet, J.F., 2004. Fusarium head blight: epidemiological origin of the effects of cultural practices on head blight attacks and the production of mycotoxins by Fusarium in wheat grains. Plant Science 166: 1389-1415.

Cirlini, M., Generotti, S., Dall'Erta, A., Lancioni, P., Ferrazzano, G., Massi, A., Galaverna, G. and Dall'Asta, C., 2014. Durum wheat (Triticum Durum Desf.) lines show different abilities to form masked mycotoxins under greenhouse conditions. Toxins 6: 81-95.

D'Mello, J.P.F., MCDonald, A.M.C. and Rinna, R., 2001. Effect of azoxystrobin on mycotoxin production in a carbendazim-resistant strain of Fusarium sporotrichioides. Phytoparasitica 29: 431-440.

De Boevre, M., Diana Di Mavungu, J., Landschoot, S., Audenaert, K., Eeckhout, M., Maene, P., Haesaert, G. and De Saeger, S., 2012. Natural occurrence of mycotoxins and their masked forms in food and feed products. World Mycotoxin Journal 5: 207-219.

De Boevre, M., Jacxsens, L., Lachat, C., Eeckhout, M., Di Mavungu, J.D., Audenaert, K., Maene, P., Haesaert, G., Kolsteren, P., De Meulenaer, B. and De Saeger, S., 2013. Human exposure to mycotoxins and their masked forms through cereal-based foods in Belgium. Toxicology Letters 218: 281-292.

Doohan, F.M., Brennan, J. and Cooke, B.M., 2003. Influence of climatic factors on Fusarium species pathogenic to cereals. European Journal of Plant Pathology 109: 755-768.

Edwards, S.G., 2004. Influence of agricultural practices on Fusarium infection of cereals and subsequent contamination of grain by trichothecene mycotoxins. Toxicology Letters 153: 29-35.

Edwards, S.G., Pirgozliev, S.R., Hare, M.C. and Jenkinson, P., 2001. Quantification of trichothecene-producing Fusarium species in harvest grain by competitive PCR to determine the efficacy of fungicides against Fusarium head blight of winter wheat. Applied and Environmental Microbiology 67: 1575-1580.

European Commission (EC), 2006. Commission regulation No. 1881/2006, of 10 December 2006 setting maximum levels for certain contaminants in food stuff. Official Journal of the European Union L364: 5-24.

European Commission (EC), 2007. Commission Regulation (EC) No 1126/2007 of 28 September 2007 amending Regulation (EC) No $1881 / 2006$ setting maximum levels for certain contaminants in foodstuffs as regards Fusarium toxins in maize and maize products. Official Journal of the European Union L255: 14-17.

Ghebremeskel, M. and Langseth, W., 2000. The occurrence of culmorin and hydroxy-culmorins in cereals. Mycopathologia 152(2): 103-108.

Haidukowski, M., Visconti, A., Perrone, G., Vanadia, S., Pancaldi, D., Covarelli, L., Balestrazzi, R. and Pascale, M., 2012. Effect of prothioconazole-based fungicides on Fusarium head blight, grain yield and deoxynivalenol accumulation in wheat under field conditions. Phytopathologia Mediterranea 51: 236-246.

Hooker, D.C., Schaafsma, A.W. and Tamburic-Ilincic, L., 2002. Using weather variables pre and post-heading to predict deoxynivalenol content in winter wheat. Plant Disease 86: 611-619. 
Jestoi, M., 2008. Emerging Fusarium-mycotoxins fusaproliferin, beauvericin, enniatins, and moniliformin: a review. Critical Reviews in Food Science and Nutrition 48: 21-49.

Jestoi, M., Rokka, M., Yli-Mattila, T., Parikka, P., Rizzo, A. and Peltonen, K., 2004. Presence and concentrations of the Fusarium-related mycotoxins beauvericin, enniatins and moniliformin in finnish grain samples. Food Additives and Contaminants 21: 794-802.

Jones, D.R., Jenkinson, P., Clement, J.A., Turner, J.E., Jennings, P. and Gladders, P., 1997. Epidemiology and control of Fusarium ear blight. HGCA Project Report No. 143.

Lazzaro, I., Busman, M., Battilani, P. and Butchko, R.A.E., 2012. FUM and BIK gene expression contribute to describe fumonisin and bikaverin synthesis in Fusarium verticillioides. International Journal of Food Microbiology 160: 94-98.

Lemmens, M., Scholz, U., Berthiller, F., Dall'Asta, C., Koutnik, A., Schuhmacher, R., Adam, G., Buerstmayr, H.,Mesterházy, A., Krska, R. and Ruckenbauer, P., 2005. The ability to detoxify the mycotoxin deoxynivalenol colocalizes with a major quantitative trait locus for Fusarium head blight resistance in wheat. Molecular Plant-Microbe Interactions 18: 1318-1324.

Lindblad, M., Gidlund, A., Sulyok, M., Börjesson, T., Krska, R., Olsen, M. and Fredlund, E., 2013. Deoxynivalenol and other selected Fusarium toxins in Swedish wheat - occurrence and correlation to specific Fusarium species. International Journal of Food Microbiology 167: 284-291.

Malachova, A., Sulyok, M., Beltran, E., Berthiller, F. and Krska, R., 2014. Optimization and validation of a quantitative liquid chromatography-tandem mass spectrometric method covering 295 bacterial and fungal metabolites including all relevant mycotoxins in four model food matrices. Journal of Chromatography A 1362: 145-156.

Matthies, A. and Buchenauer, H., 2000. Effect of tebuconazole (Folicur) andprochloraz (Sportak) treatments on Fusarium head scab development, yield, and deoxynivalenol (DON) content in grains of wheat following artificial inoculation with Fusarium culmorum. Journal of Plant Diseases and Protection 107: 33-52.

McCormick, S.P., Harris, L.J., Alexander, N.J., Ouellet, T., Saparno, A., Allard, S. and Desjardins, A.E, 2004. Tri1 in Fusarium graminearum encodes a P450 oxygenase. Applied and Environmental Microbiology 70: 2044-2051.

Menniti, A.M., Pancaldi, D., Maccaferri, M. and Casalini, L., 2003. Effect of fungicides on Fusarium head blight and deoxynivalenol content in durum wheat grain. European Journal of Plant Pathology 109: 109-115.

Mesterházy, A., Bartók, T. and Lamper, C., 2003. Influence of wheat cultivar, species of Fusarium, and isolate aggressiveness on the efficacy of fungicides for control of Fusarium head blight. Plant Disease 87: 1107-1115.

Mishra, S., Ansari, K.M., Dwivedi, P.D., Pandey, H.P. and Das, M., 2013. Occurrence of deoxynivalenol in cereals and exposure risk assessment in Indian population. Food Control 30: 549-555.

Müllenborn, C., Steiner, U., Ludwig, M. and Oerke, E.C., 2007. Effect of fungicides on the complex of Fusarium species and saprophytic fungi colonizing wheat kernels. European Journal of Plant Pathology 120: $157-166$
Müller, M.E.H. and Korn, U., 2013. Alternaria mycotoxins in wheat - a 10 years survey in the Northeast of Germany. Food Control 34: 191-197.

Müller, M.E.H., Steier, I., Koppen, R., Siegel, D., Proske, M., Korn, U. and Koch, M., 2012. Cocultivation of phytopathogenic Fusarium and Alternaria strains affects fungal growth and mycotoxin production. Journal of Applied Microbiology 113: 874-887.

Palacios, S.A., Ramirez, M.L., Cabrera Zalazar, M., Farnochi, M.C., Zappacosta, D., Chiacchiera, S.M., Reynoso, M.M., Chulze, S.N. and Torres, A.M., 2011. Occurrence of Fusarium spp. and fumonisin in durum wheat grains. Journal of Agricultural and Food Chemistry 59: 12264-12269.

Parry, D.W., Jenkinson, P. and McLeod, L., 1995. Fusarium ear blight (scab) in small grain cereal a review. Plant Pathology 44: 207-238.

Paul, P.A., Lipps, P.E., Hershman, D.E., McMullen, M.P., Draper, M.A. and Madden L.V., 2008. Efficacy of triazole-based fungicides for Fusarium head blight and deoxynivalenol control in wheat: a multivariate meta-analysis. Phytopathology 98: 999-1011.

Pedersen, P.B. and Miller, J.D., 1999. The fungal metabolite culmorin and related compounds. Natural Toxins 7: 305-309.

Pestka, J.J. and Smolinski, A.T., 2005. Deoxynivalenol: toxicity and potential effects on humans. Critical Reviews. Journal of Toxicology and Environmental Health Part B 8: 39-69.

Pirgozliev, S.R., Edwards, S.G., Hare, M.C. and Jenkinson, P., 2002. Effect of dose rate of azoxystrobin and metconazole on the development of Fusarium head blight and the accumulation of deoxynivalenol (DON) in wheat grain. European Journal of Plant Pathology 108: 469-478.

Pirgozliev, S.R., Edwards, S.G., Hare, M.C. and Jenkinson, P., 2003. Strategies for the control of Fusarium head blight in cereals. European Journal of Plant Pathology 109: 731-742.

Prelle, A., Spadaro, D., Garibaldi, A. and Gullino, M.L., 2013. A new method for detection of five Alternaria toxins in food matrices based on LC-APCI-MS. Food Chemistry 140: 161-167.

Ransom, J.K. and McMullen, M.V., 2008. Yield and disease control on hard winter wheat cultivars with foliar fungicides. Agronomy Journal 100: 1130-1137.

Scott, P.M., 2012. Recent research on fumonisins: a review. Food Additives and Contaminants Part A 29: 242-248.

Shimshoni, J.A., Cuneah, O., Sulyok, M., Krska, R., Galon, N., Sharir, B. and Shlosberg, A., 2013. Mycotoxins in corn and wheat silage in Israel. Food Additives and Contaminants Part A 30: 1614-1625.

Simpson, D.R., Weston, G.E., Turner, J.A., Jennings, P. and Nicholson, P., 2001. Differential control of head blight pathogens of wheat by fungicides and consequences for mycotoxin contamination of grain. European Journal of Plant Pathology 107: 421-431.

Streit, E., Schwab, C., Sulyok, M., Naehrer, K., Krska, R. and Schatzmayr, G., 2013. Multi-mycotoxin screening reveals the occurrence of 139 different secondary metabolites in feed and feed ingredients. Toxins 5: 504-523.

Sulyok, M., Berthiller, F., Krska, R. and Schuhmacher, R., 2006. Development and validation of a liquid chromatography/tandem mass spectrometric method for the determination of 39 mycotoxins in wheat and maize. Rapid Communications in Mass Spectrometry 20: 2649-2659. 
Sulyok, M., Krska, R. and Schuhmacher, R., 2007. A liquid chromatography/tandem mass spectrometric multi-mycotoxin method for the quantification of 87 analytes and its application to semi-quantitative screening of moldy food samples. Analytical and Bioanalytical Chemistry 389: 1505-1523.

Uhlig, S., Eriksen, G.S., Hofgaard, I. S., Krska, R., Beltrán, E. and Sulyok, M., 2013. Faces of a changing climate: semi-quantitative multi-mycotoxin analysis of grain grown in exceptional climatic conditions in norway. Toxins 5: 1682-1697.

Uhlig, S., Jestoi, M. and Parikka, P., 2007. Fusarium avenaceum - the North European situation. International Journal of Food Microbiology 119: 17-24.
Van der Fels-Klerx, H.J., Van Asselt, E.D., Madsen, M.S. and Olesen, J.E., 2013. Impact of climate change effects on contamination of cereal grains with deoxynivalenol. PloS ONE 8: 1-10.

Wang, Y.M., Liu, J.B. and Peng, S.Q., 2009. Effects of Fusarium mycotoxin butenolide on myocardial mitochondria in vitro. Toxicology Mechanisms and Methods 19: 79-85.

Zadoks, J.C., Chang, T.T. and Konzak, C.F., 1974. A decimal code for the growth stages of cereals. Weed Research 14: 415-421. 